\title{
INTERAKSI KOMUNITAS MUSLIM DAN BUDHA DI KOTA PEKANBARU
}

\author{
Khotimah \\ Dosen Fakultas Ushuluddin UIN Suska Riau \\ Email: khotimah@uin-suska.ac.id
}

\begin{abstract}
Abstrak
Bentuk. jalinan interaksi yang terjadi antara individu dan individu, individu dan kelompok, dan kelompok dan kelompok bersifat dinamis dan mempunyai pola tertentu. Apabila interaksi sosial tersebut diulang menurut pola yang sama dan bertahan untuk jangka waktu yang lama, akan terwnjud bubungan sosial yang relatif mapan. Sebagaimana yang ada pada komunitas Muslim dan Budha di Kota Pekanbaru, kbususnya di Kecamatan Senapelan terbangun pola interaksi yang sangat kondusif, yaitu pola Interaksi Individu dengan Kelompok dan interaksi kelompok dengan kelompok yang didasari oleh ikatan satu kesatuan wilayah serta di dukung oleh pemerintah setempat.
\end{abstract}

Kata kunci; Muslim, Budha, Interaksi

\section{Pendahuluan}

Secara substansi setiap agama pada hakekatnya adalah mengajarkan pada kebaikan untuk menuju pada kebahagiaan hidup di dunia serta kebahagiaan hidup sesudah kematian. Di samping itu juga agama memiliki peran sosial ditengahtengah masyarakat. Peran tersebut sangat berkaitan dengan pemenuhan kebutuhan manusia untuk mempertahankan kelangsungan hidup dan pemeliharaannya.

Secara sosiologis, pengaruh agama bisa di lihat dari dua sisi, yaitu pengaruh yang bersifat poistif atau pengaruh yang menyatukan (Integratif factor) dan pengaruh yang bersifat negatif atau pengaruh yang bersifat destruktif dan memecah belah (desintegratiffactor) (Wach, 1971).
Peranan sosial agama sebagai faktor integratif bagi manusia berarti peran agama dalam menciptakan suatu ikatan bersama, baik diantara anggota beberapa masyarakat maupun dalam kewajiban-kewajiban sosial yang membantu mempersatukan mereka. Hal ini dikarenakan nilai-nilai yang mendasari sistem kewajiban sosial didukung bersama oleh kelompok-kelompok keagamaan sehingga agama menjamin adanya konsesus dalam masyarakat (Notingha, 1992). Hal ini juga diperkuat oleh konsep sakral yang ada dalam nilai-nilai keagamaan sehinga hal tersebut tidak akan mudah diubah, dan bahkan memiliki otoritas yang sangat kuat ditengah-tengah masyarakat.

Di samping agama memiliki peranan sebagai penguat yang dapat 
mempersatukan, mengikat, dan sekaligus memelihara eksistensi suatu masyarakat, namun pada saat yang sama juga agama dapat memainkan peran untuk menceraiberaikan bahkan menghancurkan eksisitensi masyarakat itu sendiri (Marton, 1949). Hal ini merupakan konsekuensi dari begitu kuatnya agama dalam mengikat kelompok penganutnya sehingga kadang-kadang mengabaikan dan bahkan menyalahkan eksistensi pemeluk agama yang lain.

Hendropuspito (1983:151) minimal mencatat empat bentuk konflik sosial yang bersumber pada agama, yaitu perbedaan doktrin dan sikap mental, perbedaan suku dan ras pemeluk agama serta perbedaan tingkat kebudayaan serta masalah mayoritas dan minoritas kelompok agama.

Dalam konteks ini konflik sebagai fakta sosial minimal melibatkan dua kelompok agama yang berbeda, bukan hanya sebatas konstruksi khayal semata, melainkan juga sebagai sebuah fakta sejarah yang seringkali masih sering terjadi hingga saat ini. Konflik yang muncul lebih banyak disebabkan oleh adanya perbedaan doktrin yang kemudian diikuti oleh sikap mental yang memandang bahwa hanya agama yang dianutnyalah yang benar (Claim of Truth) sedangkan kelompok paham atau agama yang lain adalah salah.

Klaim kebenaran inilah yang menjadi pemicu konflik sosial yang berlatar belakang agama. Terlebih lagi pada umumnya klaim kebenaran diikuti oleh sikap kesombongan religius, prasangka, fanatisme, dan intoleransi. Sikap-sikap seperti ini sedikit banyak telah menutup sisi rasional yang sebenarnya dapat dikembangkan untuk membangun saling pengertian antar pemeluk agama.

Seringkali sisi non - rasional dan supra - rasional ini yang memegang peranan penting dalam agama, hal ini dijadikan senjata untuk menolak argumentasi rasional yang ada. Kenyataan inilah yang turut memberikan kontribusi akan eksisitensi sikap-sikap tersebut. Meskipun tidak sedikit bukti yang menunjukkan bahwa agama memiliki peran dalam mempersatukan orang-orang yang memiliki perbedaan suku dan ras, namun kita juga tidak bisa membantah bahwa seringkali perbedaan suku dan ras menimbulkan konflik sosial.

Di sisi lain sebagai bagian dari kebudayaan, agama merupakan faktor penting bagi pembudayaan manusia khususnya, dan alam semesta pada umumnya. Dengan kata lain agama adalah upaya menciptakan alam semesta dengan cara yang suci (Berger, 1973). Dengan kerangka pemikiran bahwa agama memainkan peran dominan dalam menciptakan masyarakat budaya dan melestarikan alam semesta maka munculnya ketegangan yang disebabkan karena perbedaan tingkat kebudayaan tidak bisa dilepaskan dari peran agama dalam menyediakan nilai-nilai yang disatu sisi mendorong pertumbuhan pemikiran bagi perkembangan budaya dan disisi lain justru menghambat dan mengekang pemikiran tersebut. 
Dengan demikian, bagaimana pemeluk agama memahami serta menafsirkan ajaranajaran agamanya akan sangat menentukan kemajuan atau kemunduran masyarakat pemeluknya dalam menghadapi fenomena kehidupan sosial yang berubah dengan sangat cepat. Sebagaimana yang biasa terjadi dalam suatu masyarakat yang plural, masalah mayoritas dan minoritas seringkali menjadi faktor penyebab munculnya konflik sosial.

Hendropuspito (1983:165) menyebutkan bahwa minimal ada tiga hal yang diperhatikan dalam melihat fenomena konflik minoritas dan mayoritas, yaitu pertama :agama diubah menjadi suatu idiologi, kedua: prasangka mayoritas terhadap minoritas atau sebaliknya. Ketiga: mitos dari mayoritas.

Sebagaimana yang biasa terjadi bahwa suatu kelompok agama yang mayoritas seringkali mengembangkan suatu bentuk idiologi yang bercampur dengan mitos yang penuh emosi sehingga sulit untuk dibedakan mana kepentingan politik dan mana yang kepentingan agama, telah menimbulkan suatu keyakinan bahwa kelompok mayoritas inilah yang memiliki wewenang untuk menjalankan segala aspek kehidupan di masyarakat (Hendropuspito,1983). Kondisi inilah yang kadangkala melahirkan prasangka dan tindakan sewenang-wenang terhadap kelompok minoritas yang akan bermuara pada timbulnya konflik sosial.

Di Indonesia keraagaman agama tidak menjadi penghalang untuk menciptakan sebuah kerukunan.Dimana kita tahu bahwa agama Budha merupakan agama terbesar di Asia Tenggara, dengan berbagai peristiwa di Asia hubungan antara Komunitas Muslim dan Komunitas Budha tercatat memiliki diskomunikasi yang melahirkan konflik berdarah dibeberapa tempat. Kasus Muslim Rohingya dengan Penganut Budha di beberapa wilayah di Asia Tenggara.

Oleh karena itulah, penelitian ini akan melakukan penelusuran tentang Komunitas Budha Tridharma yang secara historis memiliki waktu yang panjang di Riau khususnya di Kota Pekanbaru. Seingga perlu adanya sebuah kajian khusus yang perlu diungkap bagaimana interaksi Muslim dan Komunitas Budha Tridharma di Kota Pekanbaru ? serta bagaimana pola interaksi tersebut? Sehingga akan ditemukan sebuah bangunan yang tepat dan dapat dijadikan sebagai upaya menciptakan Tri Kerukunan di Indonesia.

Dalam penelitian ini rumusan yang diambil adalah bagaimana Bentuk serta faktor terbangunnya interaksi komunitas Muslim dan komunitas Budha Tridharma di Kota Pekanbaru? Signifikasi perlunya penelitian ini di dasarkan pada kajian penelitian sebelumnya yang pernah penulis lakukan di daerah lain. Masalah interaksi sosial memiliki nilai signifikasi yang tinggi bagi instansi yang memerlukan informasi ini, sebagai tindak lanjut untuk kebijakan pembangunan.

Dalam konteks akademisi penelitian seperti ini sangat bermanfaat bagi para 
mahasiswa khususnya bagi mahasiswa Studi Agama-Agama dan juga bagi para dosen yang konsen terhadap kajian Agama-agama. Pentingnya penelitian ini untuk mengetahui interaksi sosial komunitas Muslim dan Komunitas Tridharma sebagai bukti eksistensi komunitas Budha Tridharma yang memiliki hubungan interaksi yang harmonis dengan komunitas Muslim di Kota Pekanbaru. Karena itu penelitian ini melihat lebih dekat pola interaksi yag terbangi. Penelitian ini akan sangat signifikan dalam rangka sebagai wujud partisipasi dalam menciptakan pembangunan bangsa.

Terwujudnya kedamaian, kehidupan yang aman dan tidak ada gesekan konflik merupakan cita-cita kebnagsaan dan idiologi dinegeri ini. Sehingga pemerintah akan dapat mewujudkan pembangunan dengan aman menuju Indonesia yang sejahtera, tanpa ada gangguan konflik yang dapat memecah belah kesatuan bangsa.

Penelitian ini merupakan penelitian kualitatif, yaitu sebagaimana pendapat Patton (1980:43) dalam bukunya "Qualitative Evalution Methods, yang menyatakan bahwa data kualitatif hanya bisa didapat dengan mendekati secara fisik dan psikologis fenomena yang dikaji. Karena itu alasan menggunakan metode ini supaya dapat memahami makna tindakan para responden melalui perkataan mereka sendiri.

Pendekatan kualitatif adalah
pendekatan yang dilakukan
mengumpulkan informasi dalam

kata-kata atau keterangan-keterangan dengan tidak memerlukan perhitungan angka.

Karena penelitian ini bersifat kualitatif, sumber datanya bersifat purposive sampling di mana sampling diambil bukan dari populasi melainkan sesuai dengan tujuan penelitian. Dalam sampel purposive peneliti cenderung memilih responden yang dapat dipercaya untuk menjadi sumber data serta mengetahui masalah secara mendalam. Dengan demikian penetapan responden bukan ditentukan oleh pemikiran bahwa ia representatif terhadap populasinya melainkan responden harus representatif terhadap informasi yang diperlukan.

Adapun metode yang digunakan dalam pengumpulan data adalah Observasi, yaitu teknik yang dilakukan dengan cara pengamatan langsung. Dalam artian penelitian observasi dapat dilakukan dengan tes, kuesioner, rekaman gambar, rekaman suara" (Arikunto, 2000, 15). Teknik pengumpulan data melalui observasi adalah melakukan pengamatan secara langsung terhadap subyek atau informan penelitian (Faisal,1990).

selanjutnya, Wawancara ( Interview ) Interview/wawancara/kuesioner lisan adalah sebuah dialog yang dilakukan oleh pewawancara/interviewer untuk memperoleh informasi dari terwawancara Interview ini digunakan oleh peneliti untuk nilai keadaan seseorang. Secara garis besar, wawancara terbagi menjadi dua bagian, yaitu wawancara tidak terstruktur dan 
wawancara terstruktur. Sedangkan dalam teknik penelitian ini, jenis wawancara yang digunakan adalah wawancara tidak terstruktur yang sering disebut wawancara mendalam, wawancara intensif, wawancara kualitatif dan wawancara terbuka.

Setelah data diperoleh, maka data akan dianalisis dengan menggunakan taxonomic analysis. Taxonomic analysis digunakan untuk mengungkap alasan mengapa dan bagaimana tentang makna yang terkandung, kemudian makna tersebut disusun secara sistematis. Berdasarkan jenis dan bentuk data tersebut, makna teknik analisis data dalam penelitian ini menggunakan jenis deskriptif melalui tiga alur kegiatan yaitu: (1) mereduksi data, (2) penyajian data, dan (3) penarikan simpulan.

\section{Pola-pola Interaksi Sosial}

Bentuk jalinan interaksi yang terjadi antara individu dan individu, individu dan kelompok, dan kelompok dan kelompok bersifat dinamis dan mempunyai pola tertentu. Apabila interaksi sosial tersebut diulang menurut pola yang sama dan bertahan untuk jangka waktu yang lama, akan terwujud hubungan sosial yang relatif mapan.

Pola interaksi sosial memiliki ciri-ciri sebagai berikut.

a. Berdasarkan kedudukan sosial (status) dan peranannya. Contohnya, seorang guru yang berhubungan dengan muridnya harus mencerminkan perilaku seorang guru. Sebaliknya, siswa harus menaati gurunya. b. Merupakan suatu kegiatan yang terus berlanjut dan berakhir pada suatu titik yang merupakan hasil dari kegiatan tadi. Contohnya, dari adanya interaksi, seseorang melakukan penyesuaian, pembauran, terjalin kerja sama, adanya persaingan, muncul suatu pertentangan, dan seterusnya.

c. Mengandung dinamika. Artinya, dalam proses interaksi sosial terdapat berbagai keadaan nilai sosial yang diproses, baik yang mengarah pada kesempurnaan maupun kehancuran. Contohnya, penerapan nilai-nilai agama dalam kehidupan masyarakat dapat menciptakan keteraturan sosial.

d. Tidak mengenal waktu, tempat, dan keadaan tertentu. Berarti interaksi sosial dapat terjadi kapan dan di manapun, dan dapat berakibat positif atau negatif terhadap kehidupan masyarakat. Contohnya, sebuah sekolah yang terkenal memiliki disiplin dan tata tertib yang ketat dan mendapatkan kepercayaan dari masyarakat, pada suatu ketika menjadi tercemar karena ada siswanya yang melakukan tindakan amoral. Berdasarkan bentuknya, interaksi sosial dapat diklasifikasikan menjadi tiga pola, yaitu sebagai berikut.

\section{Interaksi Individu dengan Individu}

Dalam mekanismenya, interaksi ini dipengaruhi oleh pikiran dan perasaan yang mengakibatkan munculnya beberapa fenomena, seperti jarak sosial, perasaan simpati dan antipati, intensitas, dan 
frekuensi interaksi.Jarak sosial sangat dipengaruhi oleh status dan peranan sosial.Artinya, semakin besar perbedaan status sosial, semakin besar pula jarak sosialnya, dan sebaliknya.Anda mungkin pernah menyaksikan "si kaya" (bersifat superior) yang suka menjaga jarak dengan "si miskin" (bersifat inferior) dalam pergaulan sehari-hari karena adanya perbedaan status sosial di antara mereka.

Pola interaksi individu dengan individu ditekankan pada aspek-aspek individual, yang setiap perilaku didasarkan pada keinginan dan tujuan pribadi, dipengaruhi oleh sosio-psikis pribadi, dan akibat dari hubungan menjadi tanggung jawabnya.

Contohnya, seseorang sedang tawar menawar barang dengan pedagang di pasar, orang-orang bertemu di jalan dan saling menyapa. Untuk mengukur keakraban seseorang, umumnya digunakan sosiometri seperti pada bagan berikut ini.

Gambar 1

Sosiometri.

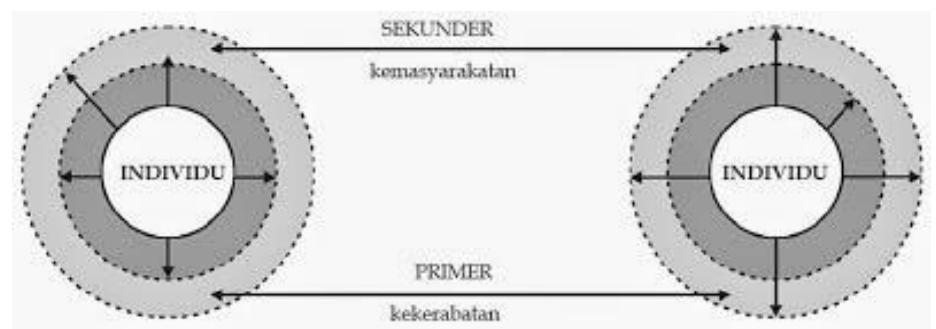

Gambar 2.

Bentuk-Bentuk Pola Interaksi

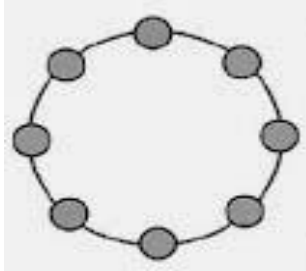

Pola lingkaran

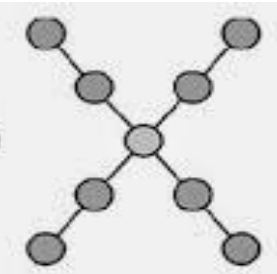

Pola huruf X

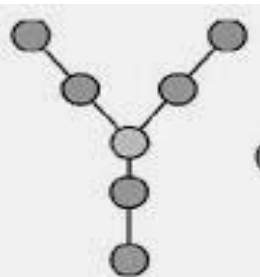

Pola huruf Y

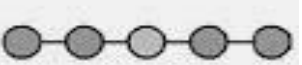

Pola garis lurus
Dari sosiometri tersebut dapat diketahui beberapa hal berikut.

a. Makin sering seseorang bergaul dengan orang lain, hubungannya akan semakin baik. Sebaliknya, makin sedikit atau jarang bergaul ia akan terasing atau terisolasi. b. Kedekatan seseorang sangat bergantung pada frekuensi dan intensitas nya melakukan pergaulan.

c. Dalam pergaulan, seseorang akan memilih atau menolak siapa yang akan dijadikan temannya. 


\section{Interaksi Individu dengan Kelompok}

Pola ini merupakan bentuk hubungan antara individu dan individu sebagai anggota suatu kelompok yang menggambarkan mekanisme kegiatan kelompoknya. Dalam hal ini, setiap perilaku didasari kepentingan kelompok, diatur dengan tata cara yang ditentukan kelompoknya, dan segala akibat dari hubungan merupakan tanggung jawab bersama.

Contohnya, hubungan antara ketua dengan anggotanya pada karang taruna tidak dikatakan sebagai hubungan antar individu, tetapi hubungan antar individu dengan kelompok sebab menggambarkan mekanisme kelompoknya. Pola interaksi individu dengan kelompok memiliki beberapa bentuk ideal yang merupakan deskripsi atau gambaran dari pola interaksi yang ada di masyarakat.

Harold Leavitt, menggambarkan terdapat empat pola interaksi ideal, yaitu pola lingkaran, pola huruf $\mathrm{X}$, pola huruf $\mathrm{Y}$, dan pola garis lurus.

Pola lingkaran merupakan pola interaksi yang menunjukkan adanya kebebasan dari setiap anggota untuk berhubungan dengan pihak manapun dalam kelompoknya (bersifat demokratis), baik secara vertikal maupun horizontal.Akan tetapi, pola ini sulit dalam menentukan keputusan karena harus ditetapkan bersama.

Pola huruf X dan Y ditandai dengan terbatasnya hubungan antar anggota kelompok sebab hubungan harus dilakukan melalui birokrasi yang kaku, tetapi mekanisme kelompok mudah terkendali karena adanya pemimpin yang dapat menguasai dan mengatur anggotanya walaupun dipaksakan. Pola garis lurus hampir sama dengan pola huruf $\mathrm{X}$ dan $\mathrm{Y}$, yang di dalamnya hubungan antaranggota tidak dilakukan secara langsung atau melalui titik sentral. Akan tetapi, pihak yang akan menjadi mediator dalam hubungan tersebut, bergantung pada individu-individu yang akan berhubungan seperti pada pola lingkaran.

\section{Interaksi Kelompok dengan Kelompok}

Hubungan ini mempunyai ciri-ciri khusus berdasarkan pola yang tampak. Pola interaksi antarkelompok dapat terjadi karena aspek etnis, ras, dan agama, termasuk juga di dalamnya perbedaan jenis kelamin dan usia, institusi, partai, organisasi, dan lainnya. Misalnya, kehidup an dalam masyarakat yang saling berbaur walaupun mereka berbeda agama, etnis atau ras; rapat antar fraksi di DPR yang membahas tentang RUU. Di antara berbagai pendekatan yang digunakan untuk mempelajari interaksi sosial, dijumpai pendekatan yang dikenal dengan nama interaksionisme simbolik. Pendekatan ini bersumber pada pemikiran George Herbert Mead.

\section{Temuan Hasil Penelitian}

\section{a. Sekilas Tentang kota Pekanbaru}

Kota Pekanbaru merupakan penghubung antara wilayah pesisir Sumatera (Wilayah sekitar Selat Malaka) 
dengan darat (Sumbar). Wilayah Pekanbaru juga merupakan kota tempat berkumpulnya penduduk wilayah pegunungan dengan lautan. Wilayah ini memiliki luas 633,01 $\mathrm{Km}$ dengan ketinggian 5-50 $\mathrm{M}$ di atas permukaan laut dan memiliki iklim tropis dengan suhu berkisar antara $23^{\circ} \mathrm{C}-33^{\circ} \mathrm{C} . \quad$ Secara anstronomi kota Pekanbaru berada pada posisi $101^{0} 14^{0} 101^{0} 34$ Bujur Timur dan $0^{0} 25-0^{0} 45$ Lintang Utara, dengan batasbatas yaitu, bagian Utara berbatasan dengan kabupaten Kampar dan Siak. Di bagian Selatan berbatasan dengan kabupaten Pelalawan. Di Barat berbatasan dengan kabupaten Kampar. Selain berada di tengah Provinsi Riau, Pekanbaru juga berada di lintasan jalur transportasi darat pulau Sumatera. Hal ini menyebabkan Pekanbaru mempunyai lokasi yang strategis seiring dengan perkembangan pembangunan di wilayah Sumatera maupun perkembnagan di Malaysia dan Singgapura.

Tipologi Kota Pekanbaru memiliki bentuk yang bervariasi, yaitu landai, berombak dan bergelombang, dengan geologi lahan yang terdiri dari endapan alluvium muda yang berbentuk akibat pengangkutan dan pengendapan sisa-sisa bahan induk oleh aliran sungai. Lahan seperti ini memiliki karakteristik yang rentan terhadap gangguan alami atau pengolahan lahan yang berlebihan. Sebagian lahan kota Pekanbaru juga mempunyai ciri formasi minas (Opmil) yang karakteristiknya lebih baik namun memiliki kandungan mineral lempung koalit yang mempunyai sifat porositas tanah rendah, yang dapat menahan senyawa alumunium, sehingga tanah bersifat asam dan sangat korosif terhadap material logam. Akibat kondisi ini jenis tanah di kota Pekanbaru bervariasi, antara lain alluvial hidromorf, alluvial kelabu, alluvial coklat kekuningan dan juga tanah-tanah yang memiliki percampuran yaitu perpaduan dua jenis tanah yang sulit dibedakan. Sebagaimana wilayah tropislainnya Pekanbaru memiliki musim yang tropis yaitu musim hujan dan musim kemarau. Letak wilayah kota Pekanbaru diapit oleh dua sungai besar yaitu sungai Siak dan Sungai Kampar.posisi ini yang menjadikan Kota Pekanbaru menjadi wilayah yang strategis untuk dituju, karena itu julukan kota bertuah memang sangat tepat untuk Kota Pekanbaru. Sejarah menjelaskan bahwa status kota Pekanbaru dari Koptapraja berubah menjadi Kotamadya diperjuangkan oleh rakyat Riau semenjak tahun 1954 yang puncak dari perjuangan tersebut terjadi pada tanggal 31 januari - 2 Pebruari 1956 yang memutuskan supaya Riau dijadikan provinsi otonom. Hal ini dibuktikan dengan ditetapkannya UU darurat RI no.19 Tahun 1957. Selanjutnya tanggal 9 Agustus 1957 dalam lembaran Negara no 75. Karena kondisi RI yang dalam kondisi darurat realisasi pembentukan provinsi baru diselenggarakan 5 maret 1958 dengan dilantiknya Mr. S.M. Amin sebagai gubernur Riau pertama di Tanjung Pinang. 
Keinginan gubernur Riau saat itu untuk memindahkan ibu kota Provinsi riau di Pekanbaru di dasarkan pada kondisi Pekanbaru saat itu di duduki oleh pasukan tentara pusat pada tanggal 12 maret 1958 di bawah pimpinan Kaharuddin Nasution.

Ketika itu melalui surat telegram menteri Dalam Negeri No 15/15/6 kepada Gubernur Riau meminta dewan penasehat Gubernur Riau segera memberikan pertimbangan kepada Mendagri tentang pemindahan ibu kota Provinsi Riau dari Tanjung Pinang ke Pekanbaru.Berdasarkan surat tersebut Gubernur Riau membentuk panitia untuk menyelidiki pemindahan ibu kota tersebut. Hasil dari tugas panitia itu setelah di bahas di kantor Menteri Dalam Negeri. Maka keluarlah Keputusan Mendagri tentang penetapan Pekanbaru sebagai ibukota Provinsi Riau pada tanggal 20 Desember1958 No 52/1/144-25. Pelaksanaan pemindahan baru dapat direalisasikan secara berangsur-angsur sejak pebruari 1960 dimana status Pekanbaru berubah menjadi Kotamadya.

$$
\text { Status Koptapraja menjadi }
$$

Kotamadya merupakan awal dilakukannya perubahan administrasi, yaitu dibentuknya dua kecamatan yaitu Senapelan dan Kecamatan lima Puluh. Pada tanggal 26 Agustus 1961 dibentuklah DPRDGR di Pekanbaru. Jabatan wali kota diserahkan kepada Tengku Bey. Berdasarkan keputusan Gubernur Riau No 55/1999 tanggal 21 Oktober1999 pekanbaru menjadi 50 Kelurahan. Berdasarkan Perda
No 3 tahun 2003 Pekanbaru dimekarkan dari 8 Kecamatan menjadi 12 Kecamatan. Selanjutnya pada tahun 1966 diadakan lagi penyempurnaan administrasi pemerintahan Pekanbaru. Selanjutnya dalam data tahun 1988 Pekanbaru dibagi kembali dengan 92 RK dan 592 RT. Sedangkan luas kota Pekanbaru menjadi 62,96 Km2. Akan tetapi setelah diukur ulang oleh BPN, luas kota Pekanbaru menjadi 632,26 Km2. Sesuai data yang tersimpan perkembangan penduduk Pekanbaru dari Tahun 1950 sebanyak 16.413 Jiwa, tahun 1955 25. 054 jiwa, tahun 195525.054 jiwa, tahun 1960 63,407 jiwa, tahun 1965 82.500jiwa, tahun 1970132.068 jiwa, tahun 1975151.650 jiwa, tahun 1978, 169.588 jiwa. Sedangkan tahun 2005 sebanyak lebih dari 700.000 jiwa dengan luas daerah $632,26 \mathrm{Km} 2$.

Berdasarkan UU No. 22 tahun 1999 tentang pemerintahan daerah sebutan "Kotamadya" berubah menjadi "Kota" Tahun 2001 kota Pekanbaru dipimpin oleh Wali Kota Drs. H. Herman Abdullah, MM. di awalinya pemerinthan yang baru dengan status Kota jumlah kecamatan di kota Pekanbaru mengalami pemekaran menjadi 12 Kecamatan, yaitu : Bukit Raya, Lima Puluh, Marpoyan Damai, Payung Sekaki, Pekanbaru Kota, Rumbai, Rumbai Pesisir, Senapelan, Sukajadi, Tampan, Tenayan Raya dan Sail. Kota Pekanbaru memiliki jumlah penduduk yang sangat heterogen, baik secara etnis, budaya maupun agama. 
Interaksi Komuniatas Muslim dan Komunitas Budha

Dalam nelitian ini Penelitian ini, mengambil satu kecamatan yakni, kecamatan Senapelan terdiri dari 6 kelurahan yakni Kelurahan Sago, Kelurahan Kampung Dalam, Kelurahan Kampung Bandar, Kelurahan Kampung Baru, Kelurahan Padang Terubuk dan Kelurahan Padang Bulan. Masyarakat di Kecamatan ini merupakan masyarakat yang heterogen dari segi agama dan etnis. Alasan diambilnya wilayah ini adalah secara kuantitas wilyah ini memiliki komunitas agama yang heterogen dan wilayah yang mudah terjangkau oleh peneliti. Ada enam agama yang dianut masyarakat di Kecamatan Senapelan, yaitu Islam, Kristen, Katolik, Hindu, Budha (Tridharma), dan Konghucu. Sudah menjadi ciri khas umum bahwa dalam masyarakat yang heterogen sangat rentan terjadinya konflik yang berlatar agama, namun hal tersebut tidak dengan masyarakat di wilayah ini, dimana antar pemeluk agama dapat hidup saling berdampingan dan belum pernah terjadi konflik, sehingga penting untuk melihat dan mendeskripsikan mengenai bentuk-bentuk interaksi sosial yang terjadi dalam masyarakat di Kecamatan Senapelan. Pembahasan ini hanya akan mendeskripsikan bentuk-bentuk interaksi sosial antar umat Budha dan Muslim yang ada di Kecamatan Senapelan sebagai berikut:

\section{Saling Menjaga dan Melindungi}

Masyarakat di Kecamatan yang mayoritas beragama muslim dan Budha telah lama menjalin hubungan sosial yang baik. Hidup berdampingan dengan agama yang berbeda memang memiliki tantangan tersendiri untuk selalu menjaga sikap dengan perbedaan yang ada. Sebagaimana yang dituturkan oleh salah seorang warga Kelurahan Sago Kecamatan Senapelan

"Saya sudah dua puluh tahun tinggal di sini, saya muslim, namun tetangga saya beragama Budha, bahkan rumah saya tepat di depan Vihara. Selama ini saya tidak pernah terjadi konflik dengan mereka (penganut Budha), kami selalu menjaga toleransi, bagi saya perbedaan yang ada bukan berarti selalu berselisih dan bermusuhan, justru kami akrab dengan mereka, begitupun mereka memiliki sikap yang sama kepada saya. Kalau ada yang lagi musibah seperti meninggal kami saling mengunjungi. Kehidupan kami rukun dan damai tanpa terjadi konflik sekalipun."

Hal senada juga diungkapkan oleh salah seorang umat Budha yang bermukim di Jalan Dr. Leimena, dalam kesehariannya ia bergaul dengan umat Islam namun ia enggan menyinggung agama lain karena dinilai sensitif dan rawan menimbulkan konflik.

"Saya termasuk pemuda Budha yang memiliki banyak teman muslim, kami juga tidak sungkan untuk berkumpul dan ngobrol bersama mereka, mereka ramah-ramah. Obrolan kami juga nyaris tidak pernah menyinggung masalah agama, karena kami sadar hari ini isu yang mengatasnamakan agama kian sensitif dan menimbulkan konflik. Kami selalu berusaha menjaga toleransi yang baik, sehingga sampai kini saya selalu 
bergaul dengan baik dengan mereka, sebagaimana yang diajarkan oleh agama kami, saya rasa begitupun yang diajarkan oleh agama Islam". (Krisna (26 tahun)

\section{Bersaing Sehat dalam Berekonomi}

Sebagai bentuk menjaga interaksi sosial yang baik umat Budha yang membuka warung makan mencantumkan label "halal" di setiap warungnya, hal ini dilakukan untuk meyakinkan umat Islam supaya leluasa dan tidak ragu mengkonsumsi makanan mereka. Sebab di dalam Islam tidak semua makanan halal/boleh dikonsumsi, ada syarat-syarat ketat yang telah ditentukan oleh kitab suci al-Qur'an, sehingga muslim sangat berhatihati ketika berbelanja di warung makan non-muslim, termasuk Budha.

"Untuk menjaga kenyamanan dan kerukunan kami dengan umat Islam, ayam yang saya jual di sini saya beli dari pedagang muslim, sehingga saya berani memasang label "halal" di warung ini. Saya tahu bahwa di dalam Islam tidak semua makanan boleh dikonsumsi. Sehingga umat Islam yang makan di sini merasa nyaman." (Purwanti, 22 tahun)

Di sepanjang Jalan Dr. Leimena berjejer ruko-ruko yang terdiri dari para pedagang muslim dan non-muslim dan terdiri dari berbagai etnis dan suku, mereka dapat berdagang secara berdampingan tanpa pernah terjadi konflik. Mayoritas mereka menjual kuliner, ada juga yang menjual bahan-bahan bangunan, dan alat-alat elektronik.

\section{Mengedepankan}

Kerukunan

\section{Antarumat Beragama}

Dalam sesi wawancara penulis menyinggung tentang tragedi Rohingya di Myanmar yang menggemparkan dunia beberapa waktu yang lalu, sebuah konflik berkepanjangan antara umat Budha yang mayoritas dan Muslim yang minoritas. Umat Muslim menjadi bulan-bulanan karena dibantai dan diusir dari Rohingya, dalam hal ini penulis tidak membahas tentang kronologis dan faktor-faktor penyebab tragedi ini, tapi lebih mengarah pada dampak yang terjadi dari tragedi ini terhadap dinamika interaksi sosial umat Budha dan Muslim di Kelurahan Kampung dalam.

"Kami merasa khawatir dan takut kepada umat Islam setelah terjadinya tragedi Rohingya yang merugikan dan memancing kecaman serta kemarahan umat Islam sedunia. Namun ternyata semua ini di luar dugaan kami, justru umat Islam di sini tidak menjadi curiga apalagi memusuhi kami." (Ari Darwanti, 26 tahun)

Umat Budha merasa khawatir sebab selama ini konflik yang mengatasnamakan agama menjadi hal yang sensitif dan rawan terjadi pertumpahan darah. Terlebih lagi di negeri ini Islam merupakan agama mayoritas, sedangkan Budha hanya minoritas. Bisa dibayangkan jika umat Islam membalas dendam atas perlakuan segelintir umat Budha di Myanmar terhadap umat Islam di Rohingya.

Namun, umat Islam di Kecamatan Senapelan lebih memilih sikap yang bijak dalam menyikapi konflik yang terjadi di luar negeri ini. Sebesar apapun konflik Rohingya 
di sana, umat Islam tidak diajarkan untuk men-genalisir seluruh umat Budha sama seperti umat Budha di luar negeri. Begitupun sebaliknya.

"Kami selalu mengajak jamaah kami untuk selalu menjaga hubungan baik dengan umat non-muslim. Karena dalam agama Islam diajarkan untuk bergaul dengan baik kepada semua umat manusia, non-muslim bukan musuh kami, musuh kami adalah mereka yang menzhalimi kami, dari golongan manapun." (Ilham Syaherli, 45 tahun)

\section{Menjaga Ketenteraman Masyarakat}

Selama ini umat Islam dan Budha di Kecamatan Senapelan telah terbiasa hidup berdampingan dengan harmonis, sehingga jika ada gejala konflik yang akan terjadi baik dari dalam masyarakat di Kecamatan Senapelan maupun dari luar, pihak pemerintah kelurahan bekerjasama dengan tokoh agama mengadakan musyawarah untuk mencegah terjadinya konflik. Sebab jika konflik sudah terjadi, maka akan lebih susah untuk diatasi.

Bagi Islam, semua anggota masyarakat, tanpa membedakan agama, memiliki hak dan kewajiban serta tanggung jawab yang sama untuk menciptakan suasana kondusif bagi terwujudnya kerukunan, bekerjasama dan bersama-sama dalam kegiatan sosial demi kebaikan. Dalam hukum hidup bertetangga, misalnya, Islam tidak melihat perbedaan agama, semua tetangga, apapun agamanya, adalah saudara yang harus dihormati dan dijaga kepentingannya. Kehidupan bertetangga, demikian hadits
Nabi, harus dibangun atas dasar cinta dan kasih sayang. Nabi bersabda: "Demi Zat yang jiwaku berada di tangan-Nya, tidak beriman seseorang hamba, sebelum dia mencintai tetangganya seperti dia mencintai dirinya sendiri". Dalam hadits yang lain, Nabi bersabda: "Apabila kamu memasak gulai daging, maka perbanyaklah airnya dan kirim ke tetanggamu” (al-'Asqalani, 2003:243).

Pernah sekali hampir terjadi konflik diKecamatan Senapelan tepatnya di Kelurahan Sago, meski konflik yang terjadi antara umat Islam dan non-muslim, namun sebenarnya hal ini bukan ditimbulkan oleh isu agama, tapi masalah suku atau etnis. Etnis Tionghoa ingin membangun gapura Tionghoa di Jalan Leimena, namun ditentang oleh masyarakat Melayu setempat, sehingga sempat terjadi ketegangan antara kedua pihak. Namun, pada akhirnya permasalahan ini dibawa ke Pemerintah Kecamatan Senapelan dan dapat diselesaikan dengan baik.. Melalui musyawarah antara pihak kelurahan dan tokoh masyarakat akhirnya konflik ini dapat diatasi.

\section{Merasa Bersaudara Meski Berbeda}

\section{Keyakinan}

Jika terjadi musibah kematian pada masyarakat yang ada di Kecaatan Senapelan misalnya di Kelurahan kampung Bandar maka tetangga-tetangga dekat saling mengunjungi, sebagai bentuk solidaritas sesama masyarakat yang baik. Begitupun yang berbeda keyakinan ikut bersama-sama 
mengunjungi tetangga yang terkena musibah, namun mereka tidak mengikuti ritual keagamaannya, hanya ikut berkumpul sebagai bentuk ungkapan bela sungkawa dan turut berduka atas musibah yang menimpa tetangganya.

"Bagi saya tetangga-tetangga di sini adalah saudara-saudara saya juga, tidak peduli satu agama atau berbeda agama, mereka adalah saudara-saudara sebangsa dan setanah air, kami juga telah terbiasa hidup bertetangga, jadi kesedihan apapun yang menimpa mereka juga berhak kami rasakan, begitupun sebaliknya."(Sufianto, 46 tahun)

Begitupun jika ada anggota masyarakat yang sakit, tetangga yang berbeda keyakinan pun turut berpartisipasi untuk menolongnya, jika masuk rumah sakit maka para tetangga turut berduyun-duyun menjenguknya sambil menghiburnya. Bantuan sekecil apapun diberikan kepada tetangga meskipun berbeda keyakinan.

\section{Menjaga Sikap Toleransi}

Toleransi berasal dari kata toleranyang berrmakna bersifat atau bersikap menenggang (menghargai, membiarkan, membolehkan) pendirian (pendapat, pandangan, kepercayaan, kebiasaan, kelakuan, dan sebagainya) yang berbeda atau bertentangan dengan pendirian sendiri. Sedangkan toleransi menurut kamus yang disusun oleh Tim Penyusun Pusat Bahasa Departemen Pendidikan Nasional (2008:1538), berarti sifat atau sikap toleran; batas ukur untuk penambahan atau pengurangan yang masih diperbolehkan; penyimpangan yang masih dapat diterima dalam pengukuran kerja.

Perwujudan toleransi dalam pergaulan hidup umat beragama menurut alMunawwar (2005:16) direalisasikan dengan cara: pertama, setiap penganut agama mengakui eksistensi agama-agama lain dan menghormati segala hak asasi penganutnya. Kedua, dalam pergaulan bermasyarakat, setiap golongan umat beragama menampakkan sikap saling mengerti, menghormati dan saling menghargai.

Sebagai masyarakat yang hidup berdampingan dengan masyarakat yang berbeda keyakinan, masyarakat di Kecamatan Senapelan selalu mengedepankan sikap toleransi saat berhadapan dengan masyarakat yang berbeda agama. Saat umat muslim melaksanakan shalat berjamaah di Masjid dengan suara adzannya dan bacaan shalatnya, umat Budha tidak merasa terganggu, begitupun saat umat Budha melakukan upacara keagamaannya di Vihara, umat muslim dapat bersikap toleransi dan tidak pernah mengganggu. Selama ini tidak pernah terjadi teror atau kerusuhan saat berlangsung ibadah atau upacara keagamaan, sehingga keharmonisan antar umat beragama di Kecamatan Senapelan terjaga dengan baik dari masa ke masa.

"Bagi kami ibadah setiap agama adalah hak mereka masing-masing, karena dilindungi oleh undang-undang. Jadi sikap kami sebagai masyarakat yang beragam agama adalah menjaga sikap 
toleransi terhadap agama lain, sehingga kerukunan dan kedamaian masyarakat Sago selalu terjaga dengan baik." (Dewi Asrina, 35 tahun)

Sikap toleransi tersebut yang selalu dijaga oleh masyarakat di Kecamatan Senapelan dantaranya masyarakat di kelurahan Sago dan juga padang Bulan dalam menjalani kehidupan bersama antarumat beragama, sehingga interaksi sosial masyarakat dapat tercipta dengan harmonis tanpa rasa kecurigaan dan kebencian. Keharmonisan ini hendaknya bisa menjadi contoh yang baik bagi umat beragama hari ini.

Masyarakat di Kecamatan Senapelan berusaha untuk senantiasa menjaga sikap toleransi kepada umat agama lain, hal ini dilakukan guna menjaga kerukunan antar umat beragama, sebab rentan terjadi konflik yang disebabkan oleh isu agama. Dengan penuh kesadaran dan kelapangan hati masyarakat yng ada di Kecamatan Senapelan selalu mengedepankan sikap toleransi jika berhadapan dengan sesama masyarakat yang berbeda keyakinan. Dalam pelaksanaan peribadatan juga dapat berjalan dengan tertib tanpa ada gangguan dari agama lain, tidak merasa terusik dan terganggu, sehingga mereka merasa aman melakukan ibadat, baik yang dilakukan oleh umat agama mayoritas maupun minoritas di di Kecamatan Senapelan diantaranya di Kelurahan Sago.

Toleransi antar umat beragama yang dijaga dengan baik oleh masyarakat di Kecamatan Senapelan menjadi hal positif yang dapat diikuti oleh masyarakat secara umum di wilayah lainnya di Indonesia. Sebab kemaslahatan masyarakat menjadi hal yang penting, karena dapat membawa keamanan dan ketentraman masyarakat dalam melakukan aktifitas mereka seharihari.

\section{Saling Tolong Menolong}

Tolong menolong merupakan salah satu ciri manusia sebagai makhluk sosial, sebab dalam kehidupannya manusia tidak mampu hidup sendiri tanpa bantuan orang lain. Hanya Sang Pencipta satu-satunya Dzat yang mampu hidup dan berdiri sendiri tanpa membutuhkan siapapun. Setiap agama pasti mengajarkan sikap saling tolong menolong dengan sesama manusia. Dalam agama Islam perintah tolong menolong terdapat dalam kitab al-Qur'an dan Hadits, sedangkan dalam agama Budha tertulis di dalam kitab Tipitaka atau Tripitaka.

Dalam kesehariannya, masyarakat yang ada di Kecamatan Senapelan selalu berinteraksi dengan tetangga-tetangganya, baik yang satu keyakinan maupun yang berbeda keyakinan. Mulai hal-hal kecil seperti keperluan pribadi dan keperluan rumah tangga hingga hal-hal besar sebagai keperluan bersama masyarakat di Kecamatan Senapelan, misalnya di Kelurahan Sago. Interaksi yang dimaksud diwujudkan dengan saling tolong menolong dengan tetangga. Penulis menjumpai dua orang wanita yang berjalan bersama, mereka berbeda keyakinan, namun wanita yang lebih muda berusaha menuntun temannya 
yang mulai menua untuk pergi ke klinik. Ini merupakan pemandangan indah terlihat rukun dan harmonis meski keyakinan mereka berbeda, namun perbedaan keyakinan tidak menjadi alasan untuk saling menjauhi, justru kebersamaan dan sikap saling menolong lebih menjadi prioritas utama dalam berinteraksi dengan rekan yang berbeda keyakinan.

Sikap saling tolong menolong inilah diantara sebab terjaganya kehidupan antar umat beragama yang harmonis di Kecamatan Senapelan. Interaksi sosial yang baik dengan wujud tolong menolong mampu membawa kehidupan antar umat beragama di di Kecamatan Senapelan terasa damai dan memperkecil gejala konflik yang mengatasnamakan agama. Jika terjadi konflik kecil tentunya tidak lain hanyalah urusan pribadi masing-masing masyarakat.

\section{Bermusyawarah dalam Menentukan}

\section{Keputusan}

Musyawarah berasal dari bahasa Arab شَاوَرَ yang bermakna berunding atau mengatakan atau mengajukan sesuatu. Musyawarah merupakan suatu upaya bersama dengan sikap rendah hati untuk memecahkan persoalan (mencari jalan keluar) guna mengambil keputusan bersama dalam penyelesaian atau pemecahan masalah yang menyangkut urusan keduniawian.

Masyarakat di Kecamatan Senapelan selalu mengedepankan musyawarah dalam memecahkan persoalan bersama, baik dalam urusan pemerintahan, pendidikan, keagamaan, dan lain-lain. Dalam pelaksanaan musyawarah khususnya yang berkaitan tentang masalah keagamaan selalu menghadirkan tokoh agama setempat mengingat bahwa Kelurahan Sago tidak hanya memiliki penganut satu agama saja, tetapi enam agama resmi di Indonesia dianut oleh masyarakat di Kecamatan Senapelan. Sehingga pihak yang minoritas tidak merasa dikucilkan oleh pihak yang mayoritas.

Melalui musyawarah keputusan yang diambil merupakan kesepakatan bersama. Kesepakatan bersama tentu tidak mengandung unsur paksaan. Sehingga semua anggota musyawarah dapat melaksanakan hasil keputusan dengan penuh tanggung jawab. Melalui musyawarah nilai keadilan dapat tercipta, nilai kebersamaan juga dapat terjalin dengan baik. Kebersamaan yang baik bisa membawa sebuah masyarakat menjadi masyarakat yang harmonis dan mampu meminimalisir konflik di dalam masyarakat. Hal ini pula yang selalu dijaga oleh masyarakat di Kecamatan Senapelan bersama aparat pemerintah kelurahan dan tokoh-tokoh agama. Sehingga masyarakat di Kecamatan Senapelan mampu hidup berdampingan meski berbeda keyakinan.

Faktor-Faktor Interaksi Sosial Komunitas Budha dan Muslim di Kecamatan Senapelan

\section{Ikatan Kesatuan Wilayah}

Masyarakat adalah kesatuan hidup manusia yang berinteraksi menurut suatu sistem adat-istiadat tertentu yang bersifat 
kontinyu, dan yang terikat oleh suatu identitas bersama. ${ }^{1}$ Masyarakat yang dikaji dalam penelitian ini adalah masyarakat di Kecamatan Senapelan yang terdiri dari kelurahan-kelurahan. Masayarakat yang ada di Kecamatan Senapelan misalnya di Kelurahan Sago menganggap bahwa tetangganya adalah saudaranya, teman bertukar informasi dan berinteraksi dalam kesehariannya, sehingga terjalin hubungan yang erat, misalnya solidaritas sesama masyarakat di Kelurahan Sago Kecamatan Senapelan terjalin dengan baik. Sebab mereka merasa saling memiliki sikap saling menyayangi, tentunya memiliki tujuan yang sesama dalam mewujudkan kehidupan yang harmonis.

Bagi masyarakat di Kecamatan Senapelan, perbedaan agama tidak menjadi halangan untuk menjalin interaksi yang baik. Justru ajaran agama menganjurkan untuk saling menyayangi kepada seluruh umat manusia, apapun agamanya. Sebab kebaikan manusia itu tidak hanya diukur dari ketaatan beribadahnya saja, melainkan kasih sayang dan perhatian kepada sesama manusia termasuk kebaikan yang diajarkan oleh setiap agama. Dalam setiap wilayah kelurahan di Kecamatan Senapelan terikat oleh wilayah yang dihuninya, sehingga setiap peraturan di wilayah Kelurahan harus ditaati oleh seluruh masyarakat. Bersama peraturan-peraturan tersebut masyarakat melakukan interaksi yang baik

\footnotetext{
${ }^{1}$ Rohadi Abdul Fatah, Sosiologi

Agama(Jakarta Selatan: Kencana Mas Publishing
}

House, 2004), 26 dengan sesama masyarakat yang ada di setiap kelurahan tersebut.. Berbagai aktifitas sehari-hari mereka tidak dapat terlepas dengan masyarakat lainnya. Sehingga mereka senantiasa menjaga keharmonisan kehidupan masyarakat sebaik mungkin.

\section{Pemerintah Wilayah setempat}

Diantara bentuk masyarakat yang baik adalah masyarakat yang mampu mencegah terjadinya konflik di dalam masyarakat tersebut. Gejala konflik pasti terjadi di setiap masyarakat. Namun, sikap bijak masyarakat yang mempengaruhi terhindarnya konflik yang akan terjadi. Hal ini dapat diwujudkan oleh masyarakat di Kecamatan Senapelan, berkat kerjasama yang baik oleh berbagai pihak, keharmonisan hidup sesama masyarakat di Kecamatan senapelan terjaga dengan baik. Pro aktif serta pengawasan dari para pimpinan dari tingkat RT, RW, Kelurahan dan juga Kecamatan dalam melakukan pengawasan dan kontrol terhadap masyarakatnya apalagi jika terkait dengan masalah interaksi sosial dalam masyarakat.

Dengan demikian, bahwa interaksi antara komunitas Muslim dan Budha) di Kota Pekanbaru terutama di Kecamatan Senapelan terbangun dengan baik dengan pola yang sangat kondusif, yaitu pola Interaksi Individu dengan individu, kelompok dengan kelompok dan interaksi kelompok dengan kelompok yang didasari oleh ikatan satu kesatuan wilayah serta di dukung oleh pemerintah setempat.

\section{Kesimpulan}


Berdasarkan penjelasan di atas, maka dapat diambil suatu kesimpulan bahwa interaksi sosial komunitas Muslim dan budha di Kota Pekanbaru terjalin dengan baik. indikatornya dapat dlihat dari hasil penelitian tersebut bahwa pola interaksi antara individu dengan individu, individu dengan kelompok ataupun kelompok dengan kelompok terbangun dengan baik yang dibuktikan dengan kerjasama yang baik dalam keseharian rutinitas kegiatan sosial serta dukungan dari pemerintah setempat. 


\section{DAFTAR PUSTAKA}

Ahmad Fanani,2010, Hubungan Antar Umat Beragama dalam Perspektif Lembaga Organisasi Keagamaan (Islam) Jawa Tengah, Semarang: PUSLIT IAIN walisongo.

Bogdan dan Taylor, 1975, Qualitative Evalution Methods, Sage: Newbury Park Calif .

C.H. Cooley, 1930, Sosiological Theory and Social Research, New York, Henry Holt and Company.

Depag RI,1996, Kompolasi Kompalasi Peraturan Perundangan-undangan Kerukunan Umat Beragama, Jakarta, Proyek peningkatan Kerukunan Hidup.

Dwi Narwoko, 2004, Sosiologi Teks Pengantar danTerapan , Jakarta, Kencana Prenada Media Group.

Elizabeth K Nottingha, 1992, Agama dan Masyarakat, translated by Abdul Muis Naharong Jakarta :Rajawali Press

Hendropuspito, 1983, Sosiologi Agama, Jakarta :Kanisius.

http://irwansahaja.blogspot.co.id/p/aboutus.html

Husein Muhammad, 2011, Mengaji Pluralisme Kepada Mabaguru Pencerahan, Bandung: Mizan.

Joanchim Wach, 1971 Sosiologi of Religion,, Chicago : The Chicago University Press..

Jurnal Toleransi, 2014, Toleransi Beragama Vol. 6. No.1 Januari-Juni 2014. Pekanbaru, LPPM UIN Suska Riau .

Jurnal Toleransi, 2015, Konsep Toleransi dan Sikap Beragama, Vo. 7 No. 2 Pekanbaru, LPPM UIN Suska Riau.
Rohadi Abdul Fatah, Sosiologi Agama(Jakarta Selatan: Kencana Mas Publishing House, 2004), 26.

Jurnal Toleransi, 2015, Toleransi Terhadap Kebebasan Beragama, Vol.7 No..2, Pekanbaru, LPPM, UIN Suska Riau.

Jurnal Toleransi, 2016, Interaksi Sosial Komunitas Islam dan Kristen di Desa tarai Bangun Kampar, Volume 5 No.2 Juli-Desember LPPM UIN Suska Riau

M. Atho Mudzhar, Jurnal Toleransi2004, "(Tantangan) Kontribusi Agama dalam Mewnijudkan Multikulturalisme di Indonesia", Makalah Sarasehan Nasional Menghidupkan dan Memantapkan Multikulturalisme" kerjasama Kementerian Koordinator Bidang Kesejabteraan Rakyat dan Universitas Islam Negeri Syarif Hidayatullah Jakarta, 8 September , UIN Syahid.

M. Ikhsan Tanggok,2000, Jalan Keselamatan Melalui Agama Khonghucu Jakarta: PT. Gramedia Pustaka Utama.

M. Ikhsan Tanggok,2005, Mengenal Lebih Dekat Agama Khonghuchu di Indonesia, Jakarta :Pelita Kebajikan Aboge di antara Agama Resmi dan Negara,

M.Cholil Masyur, 1984, Sosiologi Masyarakat Desa dan Kota" Surabaya: Usaha Nasional.

Masykuri Abdillah, 2003 "Toleransi Beragama Dalam Masyarakat Demokrasi dan Multikultural" dalam Konflike Komunal di Indonesia Saat Ini, Murni Djamal (ed), (Jakarta-Leiden:Pusat Bahasa dan Budaya UIN Jakarta.

Mulyana, D.,2001,Metodologi Penelitian Kualitatif. Paradigma Baru Ilmu Komunikasi dan Ilmu Sosial Lainnya, Bandung: PT. Remaja Rosdakarya. 
Patton,1980, Qualitative Evalution Methods, Sage: Newbury Park Calif.

Peter I Berger, 1973, The Social Reality of Religion, Peguin Book, New York

Pusat Bahasa Departemen Pendidikan Nasional,2005, Kamus Besar Bahasa Indonesia Jakarta, Balai Pustaka.

Robert K.Merton, 1949, Social Theory and Social Structure,Glencoe : Te free press.

Sanapiah Faisal, 1990, ,Penelitian Kualitatif Dasar-Dasar dan Aplikeasi Malang: Y A3 Malang.

Said Agil Husin Al-Munawwar, 2005, Fikih

Hubungan Antar Agama Jakarta:

Ciputat Press.

Soejono Soekanto,1982, Pengantar Sosiologi Jakarta:PT RajaGrafindo

Sugiono,2005,Memahami Penelitian Kualitatif Bandung: CV. Alfabeta,

Suharsimi Arikunto 1980.Metode Penelitian. Jakarta : Rineka Cipta.

Tim Penyusun Pusat Bahasa Departemen Pendidikan Nasional, 2008, Kamus Bahasa Indonesia Jakarta: Pusat Bahasa

W.A Gerungan, 1983, Psikologi Sosial Bandung, Eresco.

Zakiyuddin Baidhawy,2005, Pendidikan Agama Berwawasan Multikultural, Jakarta: Erlangga. 